described the development of soil testing methods in the United States during the past fifty years.

A large number of important communications on soil nitrogen, nitrification, nitrogen fixation, soil humus, composts, loss of nitrogen from soils, residual fertility, etc., were taken up in several sections of the Congress, because it is well established that nitrogen is the key element in cereal and other food production. Field trials in temperate countries show that one pound of nitrogen applied produces 16-17 lb. of cereals or other tillage crops, while in tropical countries the production is ten times the nitrogen input. This increase seems to be determined by the humus content in the soil ; the soil humus is greater in cool countries than in the tropics. It has been estimated that approximately 1,000 million tons of grains, including corn and 700 million tons of other food materials, are produced in the world at present. This food production requires 100 million tons of combined nitrogen. But the chemical nitrogen industry is providing 7 million tons, legumes 5 million tons, precipitation about 5 million tons and farmyard manure about 2 million tons in world agriculture. In the United States 1.5-2 million tons of chemical nitrogen, 2 million tons of legume nitrogen and perhaps 1 million tons of farmyard manure nitrogen are applied, although approximately 15 million tons of nitrogen are taken out annually from the 510 million acres of agricultural lands. Hence even to-day the majority of the nitrogen need of world crops is being met by the soil nitrogen, which must be augmented in permanent agriculture. One of the easiest methods of increasing the soil nitrogen is to plough in straw after removal of grains, cornstalks, dung, grasses, legumes, etc., mixed with 50-100 lb. phosphate (as Thomas (basic) slag) per acre, as advocated by Prof. N. R. Dhar in the Congress and elsewhere. In this manner $100 \mathrm{lb}$. of atmospheric nitrogen can be fixed per acre of land and this method is applicable to both tropical and temperate countries, which require an interval of 100-150 days for adequate nitrogen fixation and liberation of available nitrogen, phos- phate and potash for crop-growth in these lands. In this connexion, it is of interest to record that the British Association for the Advancement of Science meeting held in 1949 and presided over by Sir John Russell concluded that only 3 per cent of world food production could be attributed to artificial nitrogen. Moreover, as the application of phosphates increases the yield of crop to the extent of 5-7 times the amount of phosphorus incorporated in the soil, a very large number of papers on phosphorus availability, placement, etc., were considered at the congress.

In reaching Madison, Wisconsin, via Tour 1 and leaving Madison via Tours 2 and 3 , the delegates passed through the heart of the Corn Belt, located in the twelve North Central States, which occupy the upper portion of the Mississippi Valley. The United States produces more than half the world's maize and soy beans, and approximately one-sixth of the wheat. The bulk of these is produced in the prairie soils rich in nitrogen and humus, obtained by the natural incorporation of tall grasses in the land and by absorption of sunlight at the surface soil. It seems that no other large area in the world equals these parts of the United States as regards favourable conditions of soils (prairie, chernozem and grey-brown podzolic) and climate for the production of crops. The State of Iowa is the main producing area for maize and pork, Illinois for soy beans, Wisconsin for hay and canning crops and dairy products, which form one-seventh of the milk and half the cheese produced in the United States. The legume alfalfa (lucerne) is the main hay crop and is extensively grown.

The representatives of soil science, from many countries, including the U.S.S.R., Japan, China, India, South Africa, Ghana, Sudan, Congo and all European nations, assembled in Madison, and carried on deliberations in a cordial and friendly atmosphere for creating new knowledge, leading to the progress and welfare of the common man in the world and contributed to international friendship, co-operation and stabilizing world peace.

N. R. DHAR

\title{
SOIL SURVEY IN THE WEST INDIES
}

$\mathrm{U}^{\mathrm{s}}$ NDER the general direction of Dr. T. A. Jones steady progress has been made with the soil survey work of the Regional Research Centre of the British Caribbean, which has its headquarters at the Imperial College of Tropical Agriculture in Trinidad. The first three monographs to appear, namely, "The Parish of St. Catherine, Jamaica", "The Rupununi Savannas of British Guiana", and "St. Vincent" were reviewed in Nature, 184, 27 (1959). A further seven have now been published, covering another four of the parishes of Jamaica (St. Andrew, Clarendon, St. James and St. Mary), two further groups of selected areas in British Guiana and the island of Grenada (with Carriacou)*. Two other parishes of Jamaica are reported as completed, leaving six to be done. Each memoir follows the same plan, and as each is intended to be used as a self-contained guide there is a large amount of repetition. Each is

* Regional Research Centre of the British Caribbean at the Imperial College of Tropical Agriculture, Trinidad, W.I. Soil and Land-Use Surveys. Yonographs $4-10$. 1959-60. divided into three parts : (1) Factors affecting land use (climate, geology and lithology, relief and drainage, the people and their agriculture, present position of services); (2) the soils and their capabilities; (3) recommendations. Each monograph has a soil map in a pocket and for Jamaica the scale of $1: 50,000$ has been adopted; for Grenada the rather strange scale of $1: 18,750$ has been used. The use of a series of tints and symbols in red over a black outline has enabled much detailed information to be shown on the maps with, doubtless, a minimum of expense.

Although called a "Soil and Land-Use Survey" the existing land use has not in fact been surveyed: throughout, the aim is the severely practical one of relating potential use to soils. It is interesting to note that this has led to the re-use of the older approach to soil study-the grouping of the soils according to parent geological material-since it is found that this has the closest bearing on potential. Soil series are named and used, but take a subordinate place. In fact, Dr. Jones has given his reasons 
elsewhere (J. Soil Sci., 10, 196; 1959) why the soil-profile should be abandoned as a basis of classification since soil is "essentially a part of the landscape".

It is almost inevitable, as well as desirable, that this sustained and intensive soil work in the tropics should give rise to serious heart-searching among soil scientists. At one extreme are those pedologists who contend that soils should be studied quâ soils, without any consideration for their economic use, and some who even consider only 'natural' soils should be mapped, and that those where pedogenic processes have been impeded by cultivation should be ignored. At the other end of the scale are those who urge that a soil map or a soil study has little value per se, unless related to the potential use of the land. At this end of tne scale the extreme position is taken, as by Basil Furneaux, that there is little use in mapping at all and that the only useful approach is the ad hoc investigation of a soil in relation to its specific utilization. The West Indian work is nearing the latter approach, except that detailed mapping has been combined with full laboratory investigation. Each soil type which is mapped is given in tabular form a recommended cultivation practice. It is hoped the farmer will not be alarmed to find his land requires, for example, $P S / 3 N D / V W$, which means contour ploughing in three strips, with two in cover but no drains though with vegetative barriers and stone walls. Next he is told what crops out of some 15 may be grown, and warned of special hazards, peculiarities and nutrient requirements.

Most of the West Indian islands have problems of severe population pressure on land resources, and here is a scientific approach to the solution. But how far will the recommendations be followed? How successful would they be ? It is too much to hope that they will be applied experimentally over some considerable test areas? The proof of the pudding must be in the eating.

L. DUdley Stamp

\section{THE AUSTRALIAN ATOMIC ENERGY COMMISSION}

$\mathrm{S}^{\mathrm{T}}$ EADY progress is the keynote of the seventh annual report of the Australian Atomic Energy Commission. The report, which covers the financial year ended June 30,1959 , was presented to the Senate on March 10, 1960, by Senator W. H. Spooner, the Minister of State for National Development, who stated that earlier years had been years of innovation and trial as one new activity or another was begun in furtherance of the Commission's objectives, but, as the report shows, that phase had now been left behind*.

The report is divided into seven sections dealing respectively with the search for uranium; uranium mining; raw materials including beryllium and thorium; the research programme; prospects in Australia and overseas for nuclear power; international agencies and conferences; and general activities. The financial accounts and details of research contracts, postgraduate research studentships and undergraduate scholarships, in addition to a list of the Research Establishment buildings at Lucas Heights and of the members of the staff of the Commission, are given in six appendixes.

Air-borne surveys for uranium were on a smaller scale than in previous years, because of a shift in emphasis from uranium search to regional geological mapping, and a contraction of air-borne work in general. At Rum Jungle a detailed programme of geochemical testing was carried out to the west, north-west and south of the mine, and the area was systematically explored for additional ore. Five discoveries of radioactive minerals were reported to the Commission during the year, but none proved significant as possible sources of production.

The production figures given in the report for operations at Rum Jungle show that the uranium section of the plants proceeded satisfactorily, although the production of oxide was only about three-quarters of that during 1958 because of lower grade of head feed to the treatment plant. Two companies, the United Uranium N.L., and the South Alligator Uranium N.L., both operating in the South Alligator River

* Commonwealth of Australia, 1959. (Sydney : Australian Atomic Energy Commission, 1960.) area, concluded an arrangement with the United Kingdom Atomic Energy Authority for the sale of uranium oxide to the United Kingdom of a total value of approximately six million pounds. The United Uranium's contract, of approximately five million pounds, is for the delivery of oxide during May 1959 and December 1966, and the South Alligator Uranium's contract for the delivery of the remainder during August 1959 and early 1963.

The report comments on the fact that there is at present a world surplus in uranium and that the lull in demand foreseen for the decade 1960-70 sets problems for the Australian mining industry which is now in steady production and which has sufficient ore reserves to fulfil current contracts and to meet Australia's domestic requirements until about 1980 . The Commission wishes to maintain an active mining industry in order that new reserves may be developed and to ensure that Australia's long-range needs may be met. It is therefore important that producers should secure overseas markets for their output during the late 'sixties, but in accordance with the Commonwealth Government's principles the exports must be strictly for peaceful purposes. The stockpiling of monazite was continued, but some relaxation on export was allowed. Export of beryllium ores and concentrates remained prohibited.

New buildings to provide additional permanent workshop and laboratory space at Lucas Heights were started during the year under review. These included a large metallurgy/engineering building, a special building for beryllium research, and another devoted to isotopes and technical physics. The reactor Hifar was taken up to full power, after two years of calibration and testing, and although the reactor is primarily a materials testing reactor, it has begun also production of radioisotopes for medical, scientific and industrial use. Australian industry is still hesitant in adopting radioisotope techniques, but some improvement was reported during the year. In the reactor physics section theoretical investigations were carried out with the aid of computers on the slowing down of neutrons in beryllium and graphite, and the variation with neutron energy of 